\title{
Novel Chlorination of Zirconium Dioxide at Low Temperature
}

\author{
Takatoshi HiJIKATA and Masaki KuRATA
}

\author{
Central Research Institute of Electric Power Industry (2-11-1 Iwado Kita, Komae-shi, Tokyo 201-8511, Japan)
}

Received February 26, 2009 ; Accepted June 17, 2009

\begin{abstract}
Low-temperature chlorination of zirconium dioxide using molybdenum pentachloride has been investigated below $773 \mathrm{~K}$. The chlorination ratio was measured by chemical analysis, and the products were identified by powder Xray diffraction. The results indicated that substitution of chlorine using molybdenum pentachloride significantly reduces the reaction temperature. Almost all the zirconium dioxide was converted to chloride in 30 minutes at 668 $\mathrm{K}$ when the molar ratio of molybdenum pentachloride to zirconium dioxide exceeded two. The chlorination reaction between zirconium dioxide and molybdenum pentachloride was shown to be a three-dimensional diffusion reaction satisfying the Jander equation, and the activation energy was $67 \mathrm{~kJ} / \mathrm{mole}$. Chlorination at a practical reaction rate using molybdenum pentachloride was realized at much lower reaction temperature than that using chlorine gas and carbon.
\end{abstract}

Key Words : Chlorination, Zirconium Dioxide, Molybdenum Pentachloride, Reaction Rate

\section{Introduction}

Chlorination is an important step in large-scale commercial zirconium refining. Zirconium chloride is then reduced by magnesium to yield zirconium metal. To minimize the energy consumption and the cost of chlorination facilities, various attempts has been examined to reduce the chlorination temperature ${ }^{1)}$, and kinetics of the chlorination of zirconium dioxide $\left(\mathrm{ZrO}_{2}\right)$ by chlorine in the presence of a reducing agent has been reported. ${ }^{2,3)}$ The chlorination of $\mathrm{ZrO}_{2}{ }^{1-4)}$ and zirconium silicate ${ }^{5,6)}$ have been also studied by using several reducing agents, such as carbon, carbon monoxide or carbon tetrachloride.

The chlorination reaction of $\mathrm{ZrO}_{2}$ can occur below $1000 \mathrm{~K}$ thermodynamically, but the reactions are only practical above $1000 \mathrm{~K}$ owing to the reaction rate.,3) The study of the chlorination reaction rate was reported to improve a carbon-metal oxide contact. ${ }^{2)}$ On the other hand, chlorine gas severely corrodes the container material, and the corrosion is accelerated at high temperatures. ${ }^{7)}$ The key issue of chlorination is to optimize the reaction temperature in consideration of reaction rate and the corrosion of the reactor vessel.

It is expected that the chlorination of $\mathrm{ZrO}_{2}$ below 773 $\mathrm{K}$ reacts with a high reaction rate by using molybdenum pentachloride $\left(\mathrm{MoCl}_{5}\right) ; \mathrm{MoCl}_{5}$ simultaneously performs two roles: removing oxygen atoms and providing chlorine atoms. $\mathrm{MoCl}_{5}$ should be in greater contact with $\mathrm{ZrO}_{2}$ than carbon during chlorination, because $\mathrm{MoCl}_{5}$ is a gas or liquid at the reaction temperature.

In this study, the chlorination reaction temperature between $\mathrm{ZrO}_{2}$ and $\mathrm{MoCl}_{5}$ was measured by thermal analysis, and then the chlorination reaction and reaction rate were determined by the isothermal reaction test. The chlorination of $\mathrm{ZrO}_{2}$ by $\mathrm{MoCl}_{5}$ was compared with the other chlorination of $\mathrm{ZrO}_{2}$ at chlorination temperature and reaction rate.

\section{Chlorination Process Between Zirconium Dioxide and Molybdenum Pentachloride}

The chlorination of $\mathrm{ZrO}_{2}$ by using $\mathrm{MoCl}_{5}$ was evaluated the applicability of the process by the thermodynamic calculation and the difference of the vapor pressure as follows.

The Gibbs free energy changes of the chlorination reactions were calculated between $\mathrm{ZrO}_{2}$ and $\mathrm{MoCl}_{5}$ at $500 \mathrm{~K}$ by Malt- $2^{8}$. The thermodynamic data in Malt- 2 had only molybdenum dichloride dioxide $\left(\mathrm{MoO}_{2} \mathrm{Cl}_{2}\right)$ in molybdenum oxychlorides, and the reactions were evaluated between reactions (a) and (j) in Table 1. The chlorination reactions are possible to occur thermodynamically except the reactions (a), (e), and (g), and molybdenum tetrachloride $\left(\mathrm{MoCl}_{4}\right)$ production reactions (i) and (j) are predicted to occur more easily than the other reactions. $-\Delta \mathrm{G}$ of gas $\mathrm{MoCl}_{5}$ is larger than that of liquid $\mathrm{MoCl}_{5}$. Thus, the chlorination of $\mathrm{ZrO}_{2}$ was considered to react with either of gaseous or liquid $\mathrm{MoCl}_{5}$ in the sealed vessel.

Figure 1 shows the temperature variation of the vapor pressures of the related compounds. ${ }^{9-12)}$ The vapor pressure of $\mathrm{MoO}_{2} \mathrm{Cl}_{2}{ }^{9}$ is three orders of magnitude higher than that of zirconium tetrachloride $\left(\mathrm{ZrCl}_{4}\right)^{10)}$. The vapor pressure of $\mathrm{ZrCl}_{4}$ is much higher than that of the molybdenum production compounds (molybdenum dichloride $\left(\mathrm{MoCl}_{2}\right)^{8}$, molybdenum trichloride $\left(\mathrm{MoCl}_{3}\right)^{8)}$, $\mathrm{MoCl}_{4}{ }^{11}$, and molybdenum dioxide $\left.\left(\mathrm{MoO}_{2}\right)^{12)}\right)$. After chlorination, the molybdenum production compounds were considered to be separated from $\mathrm{ZrCl}_{4}$ by the distillation.

When the regeneration reactions of molybdenum production compounds were evaluated thermodynamically between reactions $(\mathrm{k})$ and $(\mathrm{v})$ in Table 1, the molybdenum production compounds were considered to convert to $\mathrm{MoCl}_{5}$ with the chlorine gas and carbon except reaction (p). $\mathrm{MoCl}_{5}$ could be recycled as the chlorination reagent. 
Table 1 Gibbs free energies changes of chlorination reaction and regenerated reaction at 500K.

\begin{tabular}{|c|c|c|c|}
\hline No. & Chlorination reaction & $\Delta \mathrm{H}(\mathrm{kJ} / \mathrm{mole})$ & $\Delta \mathrm{G}(\mathrm{kJ} / \mathrm{mole})$ \\
\hline (a) & $\mathrm{ZrO}_{2}(\mathrm{~s})+4 / 5 \mathrm{MoCl}_{5}(\mathrm{l})=\mathrm{ZrCl}_{4}(\mathrm{~s})+2 / 5 \mathrm{MoO}_{2}(\mathrm{~s})+2 / 5 \mathrm{MoO}_{3}(\mathrm{~s})$ & -9.7 & +14.7 \\
\hline (b) & $\mathrm{ZrO}_{2}(\mathrm{~s})+4 / 5 \mathrm{MoCl}_{5}(\mathrm{~g})=\mathrm{ZrCl}_{4}(\mathrm{~s})+2 / 5 \mathrm{MoO}_{2}(\mathrm{~s})+2 / 5 \mathrm{MoO}_{3}(\mathrm{~s})$ & -64.7 & -1.3 \\
\hline (c) & $\mathrm{ZrO}_{2}(\mathrm{~s})+\mathrm{MoCl}_{5}(\mathrm{l})=\mathrm{ZrCl}_{4}(\mathrm{~s})+1 / 2 \mathrm{MoO}_{2}(\mathrm{~s})+1 / 2 \mathrm{MoO}_{2} \mathrm{Cl}_{2}(\mathrm{~g})$ & +11.0 & -4.2 \\
\hline (d) & $\mathrm{ZrO}_{2}(\mathrm{~s})+\mathrm{MoCl}_{5}(\mathrm{~g})=\mathrm{ZrCl}_{4}(\mathrm{~s})+1 / 2 \mathrm{MoO}_{2}(\mathrm{~s})+1 / 2 \mathrm{MoO}_{2} \mathrm{Cl}_{2}(\mathrm{~g})$ & -57.8 & -24.3 \\
\hline (e) & $\mathrm{ZrO}_{2}(\mathrm{~s})+4 / 3 \mathrm{MoCl}_{5}(\mathrm{l})=\mathrm{ZrCl}_{4}(\mathrm{~s})+1 / 3 \mathrm{MoCl}_{2}(\mathrm{~s})+\mathrm{MoO}_{2} \mathrm{Cl}_{2}(\mathrm{~g})$ & +61.7 & +4.7 \\
\hline (f) & $\mathrm{ZrO}_{2}(\mathrm{~s})+4 / 3 \mathrm{MoCl}_{5}(\mathrm{~g})=\mathrm{ZrCl}_{4}(\mathrm{~s})+1 / 3 \mathrm{MoCl}_{2}(\mathrm{~s})+\mathrm{MoO}_{2} \mathrm{Cl}_{2}(\mathrm{~g})$ & -30.0 & -22.0 \\
\hline$(\mathrm{g})$ & $\mathrm{ZrO}_{2}(\mathrm{~s})+3 / 2 \mathrm{MoCl}_{5}(\mathrm{l})=\mathrm{ZrCl}_{4}(\mathrm{~s})+1 / 2 \mathrm{MoCl}_{3}(\mathrm{~s})+\mathrm{MoO}_{2} \mathrm{Cl}_{2}(\mathrm{~g})$ & +45.5 & +2.5 \\
\hline (h) & $\mathrm{ZrO}_{2}(\mathrm{~s})+3 / 2 \mathrm{MoCl}_{5}(\mathrm{~g})=\mathrm{ZrCl}_{4}(\mathrm{~s})+1 / 2 \mathrm{MoCl}_{3}(\mathrm{~s})+\mathrm{MoO}_{2} \mathrm{Cl}_{2}(\mathrm{~g})$ & -56.7 & -24.7 \\
\hline (i) & $\mathrm{ZrO}_{2}(\mathrm{~s})+2 \mathrm{MoCl}_{5}(\mathrm{l})=\mathrm{ZrCl}_{4}(\mathrm{~s})+\mathrm{MoCl}_{4}(\mathrm{~s})+\mathrm{MoO}_{2} \mathrm{Cl}_{2}(\mathrm{~g})$ & +13.1 & -42.9 \\
\hline (j) & $\mathrm{ZrO}_{2}(\mathrm{~s})+2 \mathrm{MoCl}_{5}(\mathrm{~g})=\mathrm{ZrCl}_{4}(\mathrm{~s})+\mathrm{MoCl}_{4}(\mathrm{~s})+\mathrm{MoO}_{2} \mathrm{Cl}_{2}(\mathrm{~g})$ & -124.5 & -83.0 \\
\hline No. & Regeneration reaction & $\Delta \mathrm{H}(\mathrm{kJ} / \mathrm{mole})$ & $\Delta \mathrm{G}(\mathrm{kJ} / \mathrm{mole})$ \\
\hline$(\mathrm{k})$ & $\mathrm{MoCl}_{2}(\mathrm{~s})+3 / 2 \mathrm{Cl}_{2}=\mathrm{MoCl}_{5}(\mathrm{l})$ & -221.6 & -144.6 \\
\hline$(1)$ & $\mathrm{MoCl}_{2}(\mathrm{~s})+3 / 2 \mathrm{Cl}_{2}=\mathrm{MoCl}_{5}(\mathrm{~g})$ & -152.8 & -124.5 \\
\hline (m) & $\mathrm{MoCl}_{3}(\mathrm{~s})+\mathrm{Cl}_{2}=\mathrm{MoCl}_{5}(\mathrm{l})$ & -115.3 & -91.8 \\
\hline (n) & $\mathrm{MoCl}_{3}(\mathrm{~s})+\mathrm{Cl}_{2}=\mathrm{MoCl}_{5}(\mathrm{~g})$ & -46.5 & -71.8 \\
\hline (o) & $\mathrm{MoCl}_{4}(\mathrm{~s})+1 / 2 \mathrm{Cl}_{2}=\mathrm{MoCl}_{5}(\mathrm{l})$ & -25.2 & -0.6 \\
\hline (p) & $\mathrm{MoCl}_{4}(\mathrm{~s})+1 / 2 \mathrm{Cl}_{2}=\mathrm{MoCl}_{5}(\mathrm{~g})$ & +43.6 & +19.5 \\
\hline (q) & $\mathrm{MoO}_{2} \mathrm{Cl}_{2}(\mathrm{~g})+\mathrm{C}(\mathrm{s})+3 / 2 \mathrm{Cl}_{2}(\mathrm{~g})=\mathrm{MoCl}_{5}(\mathrm{l})+\mathrm{CO}_{2}(\mathrm{~g})$ & -303.2 & -256.3 \\
\hline$(\mathrm{r})$ & $\mathrm{MoO}_{2} \mathrm{Cl}_{2}(\mathrm{~g})+\mathrm{C}(\mathrm{s})+3 / 2 \mathrm{Cl}_{2}(\mathrm{~g})=\mathrm{MoCl}_{5}(\mathrm{~g})+\mathrm{CO}_{2}(\mathrm{~g})$ & -188.2 & -157.8 \\
\hline (s) & $\mathrm{MoO}_{2}(\mathrm{~s})+\mathrm{C}(\mathrm{s})+5 / 2 \mathrm{Cl}_{2}(\mathrm{~g})=\mathrm{MoCl}_{5}(\mathrm{l})+\mathrm{CO}_{2}(\mathrm{~g})$ & -257.0 & -177.8 \\
\hline$(\mathrm{t})$ & $\mathrm{MoO}_{2}(\mathrm{~s})+\mathrm{C}(\mathrm{s})+5 / 2 \mathrm{Cl}_{2}(\mathrm{~g})=\mathrm{MoCl}_{5}(\mathrm{~g})+\mathrm{CO}_{2}(\mathrm{~g})$ & -234.4 & -236.3 \\
\hline (u) & $\mathrm{MoO}_{3}(\mathrm{~s})+3 / 2 \mathrm{C}(\mathrm{s})+5 / 2 \mathrm{Cl}_{2}(\mathrm{~g})=\mathrm{MoCl}_{5}(\mathrm{l})+3 / 2 \mathrm{CO}_{2}(\mathrm{~g})$ & -230.2 & -222.4 \\
\hline (v) & $\mathrm{MoO}_{3}(\mathrm{~s})+3 / 2 \mathrm{C}(\mathrm{s})+5 / 2 \mathrm{Cl}_{2}(\mathrm{~g})=\mathrm{MoCl}_{5}(\mathrm{~g})+3 / 2 \mathrm{CO}_{2}(\mathrm{~g})$ & -276.5 & -313.6 \\
\hline
\end{tabular}

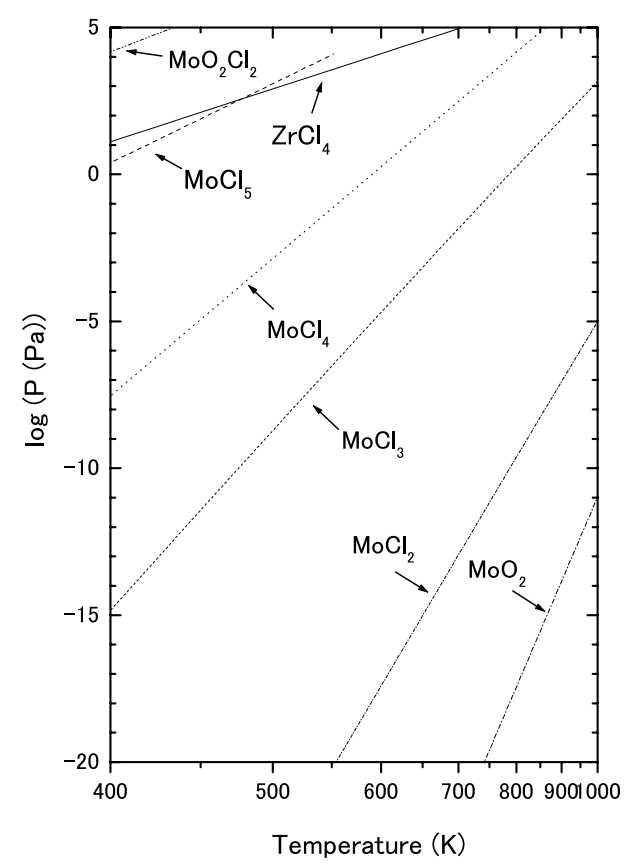

Fig. 1 Vapor pressures of $\mathrm{ZrCl}_{4}, \mathrm{MoCl}_{2}, \mathrm{MoCl}_{3}, \mathrm{MoCl}_{4}$, $\mathrm{MoCl}_{5}, \mathrm{MoO}_{2} \mathrm{Cl}_{2}$, and $\mathrm{MoO}_{2}$.

\section{1 Reagents}

\section{Experimental}

$\mathrm{MoCl}_{5}$ and $\mathrm{ZrO}_{2}$ powders were purchased from Rare Metallic Co. The purity of $\mathrm{MoCl}_{5}$ was greater than $99 \%$ and that of $\mathrm{ZrO}_{2}$ was greater than $99.9 \% . \quad \mathrm{ZrO}_{2}$ powders were dried to remove absorbed water at about $573 \mathrm{~K}$ for 5 hour in an argon atmosphere where oxygen and mois- ture contents were less than $2 \mathrm{ppm}$. The sintered $\mathrm{ZrO}_{2}$ which was a $1.5 \mathrm{~mm}$ diameter sphere had $5 \mathrm{wt} \%$ yttria, and was purchased from Nikato Co. $\mathrm{MoO}_{2} \mathrm{Cl}_{2}$ was purchased from Aldrich Co, and used the standard material of X-ray analysis.

To thermal analysis and isothermal reaction, the powder of chemicals was vacuum-sealed in Pyrex tube. 200 to $300 \mathrm{mg}$ of mixtures between $\mathrm{ZrO}_{2}$ and $\mathrm{MoCl}_{5}$ were loaded into the tubes. Since $\mathrm{MoCl}_{5}$ is deliquescent in air, the mixture and loading of samples were performed in an argon atmosphere where oxygen and moisture contents were less than $2 \mathrm{ppm}$. The molar ratio $\left(R_{\mathrm{feed}}\right)$ of $\mathrm{MoCl}_{5}$ to $\mathrm{ZrO}_{2}$ was adjusted, where the ratio $R_{\text {feed }}$ is given by

$$
R_{\text {feed }}=\frac{\text { moles of } \mathrm{MoCl}_{5}}{\text { moles of } \mathrm{ZrO}_{2}}
$$

\section{2 Thermal analysis}

The apparatus for thermal analysis (DTA) are shown in Fig. 2. The ratio $R_{\text {feed }}$ was adjusted to 1.1. The sealed tube was set in a radiation furnace as shown in Fig. 2 (b). A K-type thermocouple was inserted into a hollow at the bottom of the tube, as shown in Fig. 2 (a). Molybdenum trioxide was used as a reference material. The temperature difference $(\Delta \mathrm{T})$ between sample and reference was measured with increasing the temperature. The heating rate was $2 \mathrm{~K} / \mathrm{min}$. The samples were heated to approximately $673 \mathrm{~K}$ from room temperature, and two cycles of heating and cooling were performed.

\section{3 Isothermal reaction}

The chlorination of $\mathrm{ZrO}_{2}$ powder by $\mathrm{MoCl}_{5}$ was carried out in the sealed glass tube under isothermal condition 
from 468 to $781 \mathrm{~K}$. Powders of $\mathrm{ZrO}_{2}$ and $\mathrm{MoCl}_{5}$ were mixed with the ratio $R_{\text {feed }}$ in the range of 0.2 to 4 . The tubes were set in the furnace, and the samples were heated at fixed temperatures for several hours.

The sintered $\mathrm{ZrO}_{2}$ was employed to measure the reaction rate corrected by the surface area. 2 or 3 of sintered $\mathrm{ZrO}_{2}$ were placed in the Pyrex tube, and the ratio $R_{\text {feed }}$ was adjusted to approximately 3 by adding 0.2 to $0.3 \mathrm{~g}$ $\mathrm{MoCl}_{5}$ to the tube. The samples were heated at fixed temperatures for several hours.

Table 2 shows the experimental conditions for the isothermal chlorination reaction between $\mathrm{MoCl}_{5}$ and $\mathrm{ZrO}_{2}$.

\section{4 X-ray diffraction analysis}

The samples before/after the chlorination were measured by X-ray diffractometer (Rigaku Co., RINT-2500V).

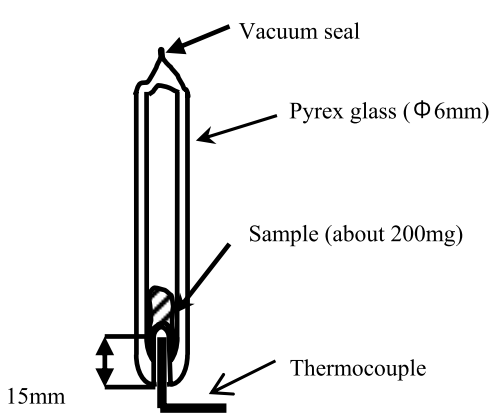

(a) Cross section of sample tube

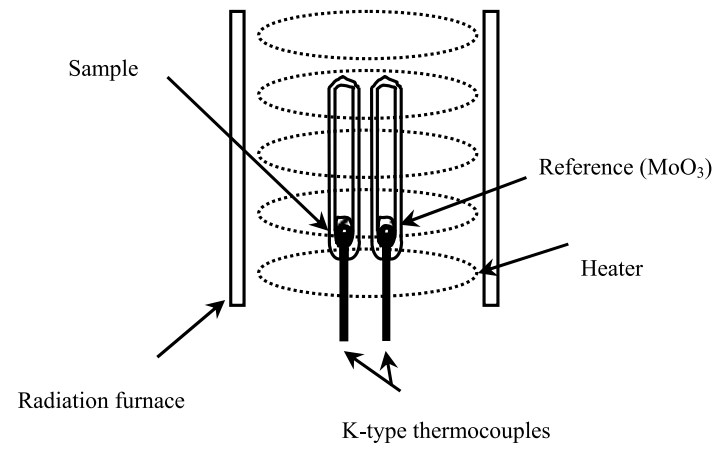

(b) Schematic image of thermal analysis furnace

Fig. 2 Apparatus used for thermal analysis of the chlorination reaction between $\mathrm{MoCl}_{5}$ and $\mathrm{ZrO}_{2}$.
The samples of the ratio $R_{\text {feed }}=1.1$ were heated at $781 \mathrm{~K}$ for 20 hour. The sample removed from the tube in an argon atmosphere was set in an X-ray sample with polyethylene cover to protect it against oxidation and deliquescence. Another sample obtained under the same chlorination condition used to separate highly volatile compounds such as $\mathrm{MoCl}_{5}, \mathrm{MoO}_{2} \mathrm{Cl}_{2}$ and $\mathrm{ZrCl}_{4}$. The bottom of the tube was heated for 7 hour at about $760 \mathrm{~K}$, and the volatile compounds condensed at the cooled top. The evaporated sample was taken from the top of the tube. The diffraction peaks were identified by reference to the Joint Committee of the Powder Diffraction Standards (JCPDS). ${ }^{13)}$

\section{5 Chemical analysis}

In this study, products formed by the reaction were assumed to include $\mathrm{ZrO}_{2}, \mathrm{ZrCl}_{4}, \mathrm{MoO}_{2}, \mathrm{MoO}_{3}, \mathrm{MoCl}_{2}$, $\mathrm{MoCl}_{3}, \mathrm{MoCl}_{4}, \mathrm{MoCl}_{5}$, molybdenum trichloride oxide $\left(\mathrm{MoOCl}_{3}\right)$, molybdenum tetrachloride oxide $\left(\mathrm{MoOCl}_{4}\right)$ and $\mathrm{MoO}_{2} \mathrm{Cl}_{2}$. The sample used in the isothermal reaction experiment was chemically analyzed to quantify the chlorination ratio by the method shown in Fig. 3. The molybdenum compounds are difficult to identify by only chemical analysis. However, the zirconium compounds can be identified by dissolving the sample in water, because $\mathrm{ZrCl}_{4}$ is soluble in water and $\mathrm{ZrO}_{2}$ is insoluble in

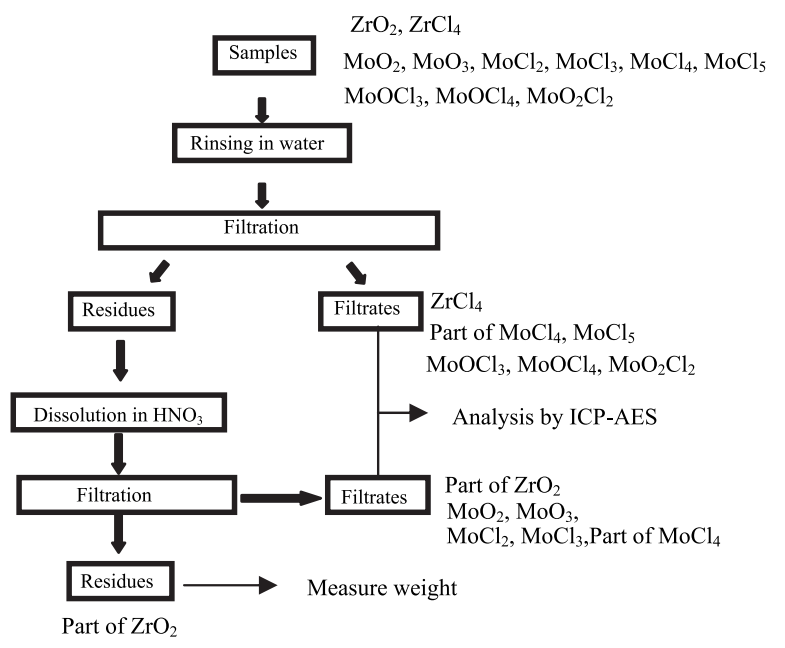

Fig. 3 Flow chart used for the chemical analysis of samples.

Table 2 Isothermal reaction experimental conditions.

\begin{tabular}{ccccc}
\hline Run & Form of $\mathrm{ZrO}_{2}$ & $\mathrm{R}_{\text {feed }}\left(\right.$ moles of $\mathrm{MoCl}_{5} /$ moles of $\left.\mathrm{ZrO}_{2}\right)$ & Temperature (K) & Time (hour) \\
\hline 1 & Powder & $0.2,0.5,1.5,2.5,5.3$ & 468 & 91 \\
\hline 2 & Powder & $0.2,0.4,0.6,1.2,2,3,2.8,4.1$ & 571 & 17 \\
\hline 3 & Powder & $0.1,0.5,0.6,2.0,2.6,3.7$ & 685 & 21 \\
\hline 4 & Powder & $0.05,0.15,0.3,0.4,1.0,1.11 .9,3.03 .5$ & 781 & 20 \\
\hline 5 & Powder & 2.6 & 473 & $0.5,1.0,2.0,7.7,91$ \\
\hline 6 & Powder & 2.6 & 561 & $0.5,2.2,3.9,7.8,24$ \\
\hline 7 & Powder & 2.6 & 668 & $0.5,1.0,4.0,7.6,24$ \\
\hline 8 & Powder & 2.6 & 773 & $0.5,1.0,2.0,4.2,7.8,24,32$ \\
\hline 9 & Sinter & $2.3-3.0$ & 640 & $0.3,4.0,7.8,8.0,16.4$ \\
\hline 10 & Sinter & $2.8-2.9$ & 674 & $2.0,2.5,3.7,6.3,7.8$ \\
\hline 11 & Sinter & $2.5-3.1$ & 723 & $0.3,0.8,1.0,1.5,2.0,3.6,5.0$ \\
\hline
\end{tabular}


water. The ratio of $\mathrm{ZrCl}_{4}$ to $\mathrm{ZrO}_{2}$ quantitatively indicated the effect of chlorinating $\mathrm{ZrO}_{2}$ using $\mathrm{MoCl}_{5}$. After the reaction, the sample was removed from the glass tube, and after weighing the sample, it was dissolved in water. This solution was filtrated by $0.45 \mu \mathrm{m}$ filter, and the filtrate concentration was adjusted to 1 mole/liter by adding nitric acid solution. Since the residue was a mixture of $\mathrm{ZrO}_{2}$ and molybdenum compounds, the residue dissolved in concentrated nitric acid, and the remaining residue was separated by filtrating. The residue after adding acid was considered to comprise only $\mathrm{ZrO}_{2}$, and after drying, the number of moles of $\mathrm{Zr}$ in the residue was obtained from its weight. The acid filtrate concentration was adjusted to 1 mole/liter by adding nitric acid solution. The amounts of zirconium in the two filtrates were measured by an inductively-coupled plasma-emission spectrometer (Shimadzu Co., ICP-1000).

The amounts of loaded $\mathrm{ZrO}_{2}$ were almost agreement with that of detected $\mathrm{ZrO}_{2}$ by the chemical analysis, however, the mass balance of $\mathrm{ZrO}_{2}$ in some ampules was given between 60 and $80 \%$, because some samples remained in the separated glass tube at the seal. The chlorination ratio of zirconium dioxide $\left(R_{\text {react }}\right)$ is given by the following equation:

$$
R_{\text {react }}=
$$

$\mathrm{Zr}$ in water soluble sample (mole)

$\overline{\text { (Zr in water soluble sample }+\mathrm{Zr} \text { in acid soluble sample }+\mathrm{Zr} \text { of residue)(mole) }}$

$(\%) . \quad(2)$

\section{Results and Discussion}

\section{1 Chlorination reaction temperature}

Figure 4 shows the DTA curves of $\mathrm{MoCl}_{5}$ and the sample (the ratio $R_{\text {feed }}=1.1$ ). An endothermic reaction in Fig. 4 (a) occurred at approximately $470 \mathrm{~K}$, which corresponds to the melting of $\mathrm{MoCl}_{5}$ (mp: $\left.463 \mathrm{~K}\right) \cdot{ }^{14)}$ As shown in Fig. 4 (b), a similar endothermic reaction of sample occurred at the same temperature, and then an exothermic reaction occurred at approximately $500 \mathrm{~K}$. Because both endothermic and exothermic peaks disappeared in the second cycle, the exothermic reaction in the first

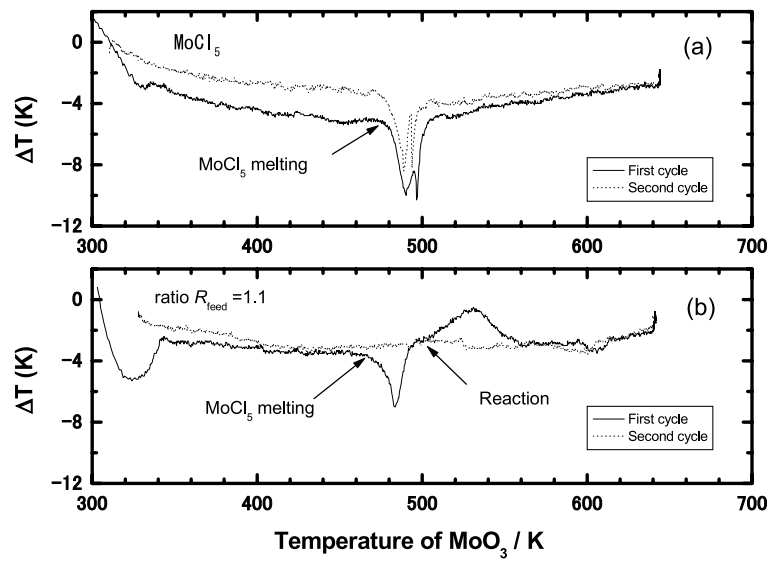

Fig. 4 DTA curves of (a) $\mathrm{MoCl}_{5}$ and (b) $\mathrm{MoCl}_{5}$ and $\mathrm{ZrO}_{2}$ (the ratio $R_{\text {feed }}=1.1$ ). cycle was irreversible. The exothermic chlorination reaction was the reactions (b), (d), (f), (g), and (j) of gaseous $\mathrm{MoCl}_{5}$ in Table 1. These results were suggested that $\mathrm{ZrO}_{2}$ reacted with $\mathrm{MoCl}_{5}$ at approximately $500 \mathrm{~K}$.

\section{2 Identification of chlorination reaction}

The X-ray diffraction patterns of the samples are shown in Fig. 5. As compared to the unreacted sample (Fig. 5 (b)), the $\mathrm{MoCl}_{5}$ peaks of the reacted sample (Fig. 5 (c)) disappeared and the new appeared peaks were $\mathrm{MoCl}_{4}$ peaks and then were identified with $\mathrm{MoO}_{2} \mathrm{Cl}_{2}$ peaks which were observed in Fig. 5 (a). The peaks in the evaporated sample observed $\mathrm{MoO}_{2} \mathrm{Cl}_{2}$ and $\mathrm{ZrCl}_{4}$, as shown in Fig. 5 (d). These results suggest that $\mathrm{ZrCl}_{4}$, $\mathrm{MoCl}_{4}$, and $\mathrm{MoO}_{2} \mathrm{Cl}_{2}$ were produced by the reaction between $\mathrm{ZrO}_{2}$ and $\mathrm{MoCl}_{5}$.

In Run 1 to 4 in Table 2, the chlorination ratio of $\mathrm{ZrO}_{2}$ (the $R_{\text {react }}$ ) was determined relative to the ratio $R_{\text {feed }}$ by the chemical analysis. The relationship between the $R_{\text {react }}$ of $\mathrm{ZrO}_{2}$ and the ratio $R_{\text {feed }}$ is shown in Fig.6. The $R_{\text {react }}$ of $\mathrm{ZrO}_{2}$ increased with increasing the ratio $R_{\text {feed }}$ up to the ratio $R_{\text {feed }}=2$, and almost all the $\mathrm{ZrO}_{2}$ was converted to $\mathrm{ZrCl}_{4}$ at the ratio $R_{\text {feed }} \geq 2$. It was necessary for the ratio $R_{\text {feed }}$ to exceed 2 to convert all the $\mathrm{ZrO}_{2}$ to $\mathrm{ZrCl}_{4}$. The relationship between the $R_{\text {react }}$ of $\mathrm{ZrO}_{2}$ and the ratio $R_{\text {feed }}$ showed the same trend at reaction temperatures from 468 to $781 \mathrm{~K}$. It is suggested that $\mathrm{ZrO}_{2}$ reacted with both gaseous and liquid $\mathrm{MoCl}_{5}$, of which boiling point is $543 \mathrm{~K}^{15)}$.

It was supposed that the chlorination of $\mathrm{ZrO}_{2}$ by using $\mathrm{MoCl}_{5}$ of gas or liquid proceeded as the following same reactions (3)-(9). The chlorination reaction between $\mathrm{ZrO}_{2}$

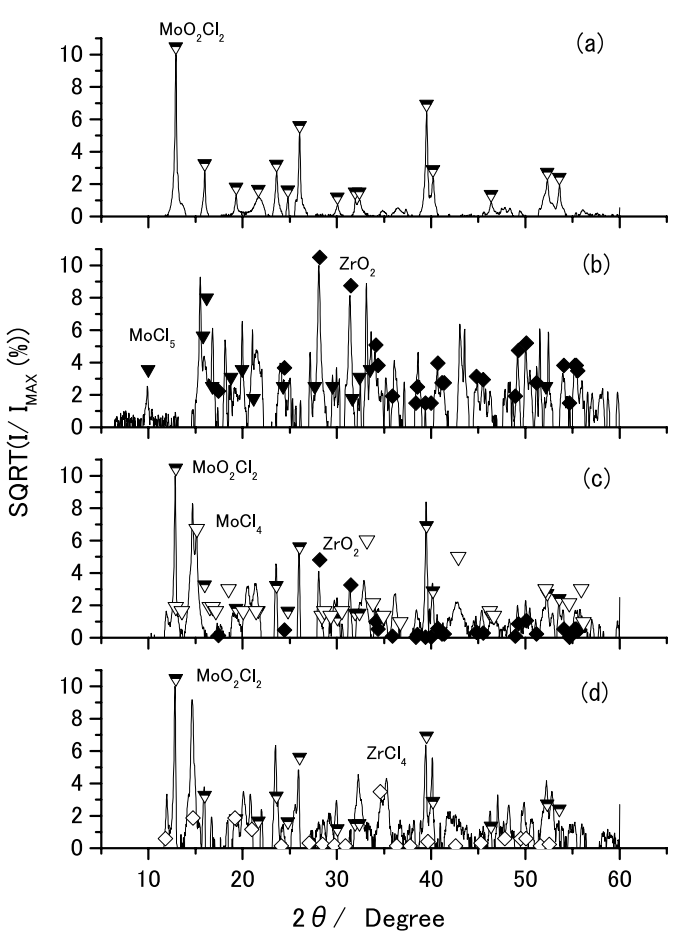

Fig. 5 X-ray diffraction patterns of the compounds formed by the reaction between $\mathrm{MoCl}_{5}$ and $\mathrm{ZrO}_{2}$ at $781 \mathrm{~K}$ for 20 hour (ratio $R_{\text {feed }}=1.1$ ). (a) $\mathrm{MoO}_{2} \mathrm{Cl}_{2}$, (b) before reaction, (c) after reaction, (d) evaporated sample. 


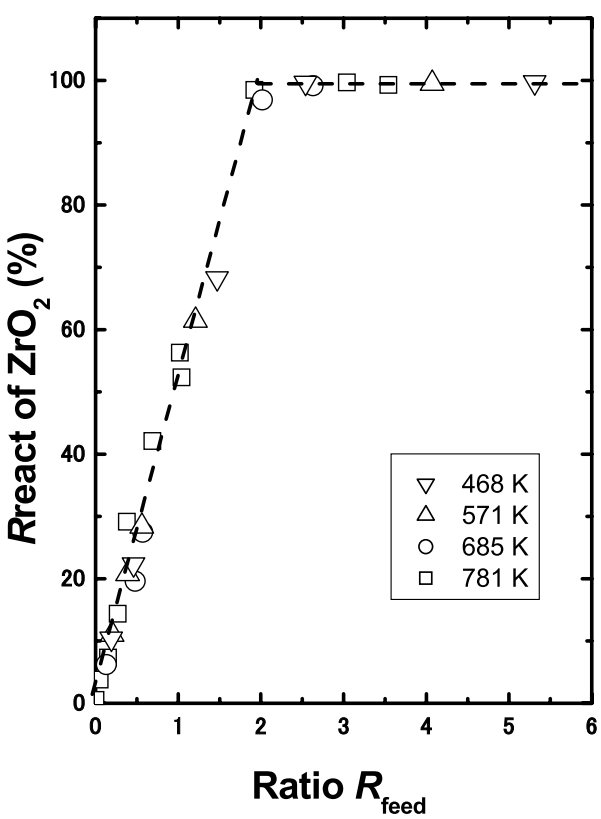

Fig. 6 Relationship between chlorination ratio of $\mathrm{ZrO}_{2}$ and molar ratio $R_{\text {feed }}$ of $\mathrm{MoCl}_{5}$ to $\mathrm{ZrO}_{2}$. Samples of $\mathrm{MoCl}_{5}$ and $\mathrm{ZrO}_{2}$ were obtained after reaching temperatures of 468,571 , 685 and $781 \mathrm{~K}$.

and $\mathrm{MoCl}_{5}$ was analyzed on the basis of the following reactions.

$$
\begin{aligned}
& \mathrm{ZrO}_{2}+4 / 5 \mathrm{MoCl}_{5}=\mathrm{ZrCl}_{4}+2 / 5 \mathrm{MoO}_{2}+2 / 5 \mathrm{MoO}_{3} \\
& \mathrm{ZrO}_{2}+\mathrm{MoCl}_{5}=\mathrm{ZrCl}_{4}+1 / 2 \mathrm{MoO}_{2}+1 / 2 \mathrm{MoO}_{2} \mathrm{Cl}_{2} \\
& \mathrm{ZrO}_{2}+4 / 3 \mathrm{MoCl}_{5}=\mathrm{ZrCl}_{4}+1 / 3 \mathrm{MoCl}_{2}+\mathrm{MoO}_{2} \mathrm{Cl}_{2} \\
& \mathrm{ZrO}_{2}+3 / 2 \mathrm{MoCl}_{5}=\mathrm{ZrCl}_{4}+1 / 2 \mathrm{MoCl}_{3}+\mathrm{MoO}_{2} \mathrm{Cl}_{2} \\
& \mathrm{ZrO}_{2}+2 \mathrm{MoCl}_{5}=\mathrm{ZrCl}_{4}+\mathrm{MoCl}_{4}+\mathrm{MoO}_{2} \mathrm{Cl}_{2} \\
& \mathrm{ZrO}_{2}+2 \mathrm{MoCl}_{5}=\mathrm{ZrCl}_{4}+2 \mathrm{MoOCl}_{3} \\
& \mathrm{ZrO}_{2}+3 \mathrm{MoCl}_{5}=\mathrm{ZrCl}_{4}+\mathrm{MoCl}_{3}+2 \mathrm{MoOCl}_{4}
\end{aligned}
$$

The chlorination reaction of $\mathrm{ZrO}_{2}$ by $\mathrm{MoCl}_{5}$ was considered to be the reactions (7) and (8) by the chemical analysis, and was shown to be the reaction (7) by the $\mathrm{X}$ ray analysis. These results were strongly suggested that $\mathrm{ZrO}_{2}$ is chlorinated by $\mathrm{MoCl}_{5}$ by the reaction (7) under the present condition.

\section{3 Reaction rate of $\mathrm{ZrO}_{2}$ chlorinated by $\mathrm{MoCl}_{5}$}

The reaction rate between $\mathrm{ZrO}_{2}$ and $\mathrm{MoCl}_{5}$ was measured by the sample of the ratio $R_{\text {feed }}=2.6$ at 473,561 , 668 and $773 \mathrm{~K}$. The relationship between the chlorination ratio of $\mathrm{ZrO}_{2}$ and reaction time is shown in Fig. 7 . Approximately 100 hour was required for the complete conversion at $473 \mathrm{~K}$. However, the reaction finished within 0.5 hour at $668 \mathrm{~K}$. The reaction time of the $\mathrm{ZrO}_{2}$ chlorinated by $\mathrm{MoCl}_{5}$ was shortening with the increase of the reaction temperature, as shown in Fig. 7. $\mathrm{ZrO}_{2}$ reacted more actively with the gaseous $\mathrm{MoCl}_{5}$ than with the liquid.

It was supposed that the chlorination reaction of $\mathrm{ZrO}_{2}$ by $\mathrm{MoCl}_{5}$ was the three-dimensional diffusion reaction, because the similar chlorination reaction of $\mathrm{ZrO}_{2}$ by using $\mathrm{CCl}_{4}$ was the three-dimensional diffusion reaction in the range of 650 to $675 \mathrm{~K}^{1)}$. The three-dimensional dif-

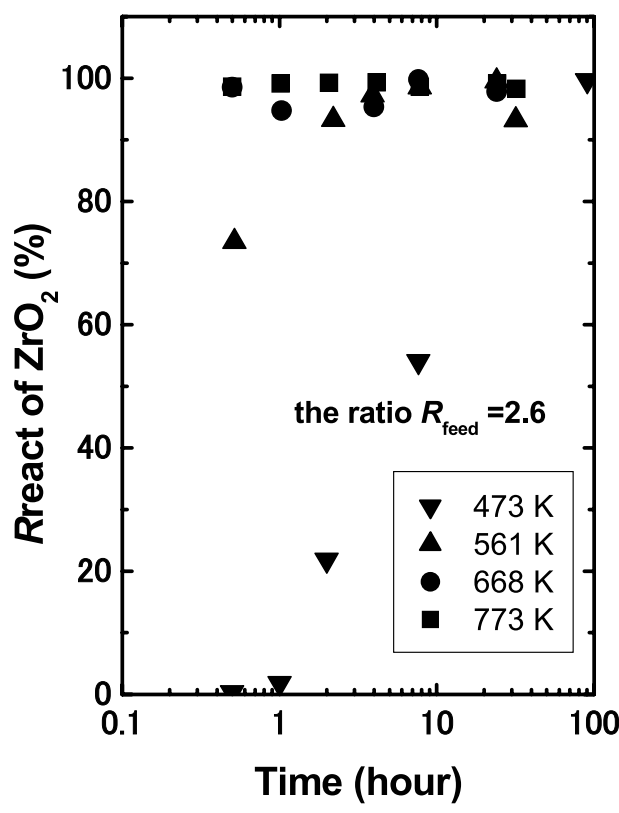

Fig. 7 Relationship between the chlorination ratio of $\mathrm{ZrO}_{2}$ and the reaction time at the temperatures of 473,561, 668, and $773 \mathrm{~K}$ (the ratio $R_{\text {feed }}=2.6$ ).

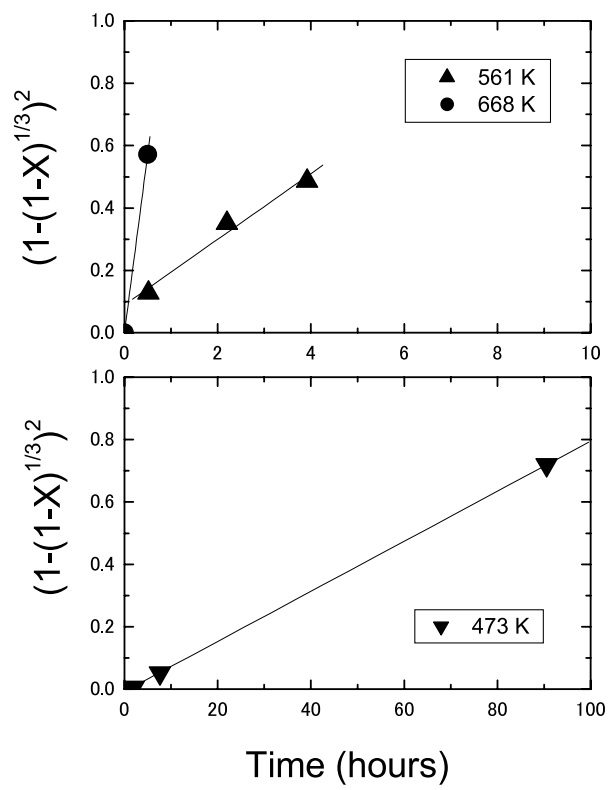

Fig. 8 Relationship between $\left[1-(1-\mathrm{X})^{1 / 3-2}\right]$ and $\mathrm{t}$ at reaction temperatures of 473,561 and $668 \mathrm{~K}$ (the ratio $R_{\text {feed }}=2.6$ ).

fusion reaction is given in Jander equation. ${ }^{16)}$

$$
\left[1-(1-\mathrm{X})^{1 / 3-2}\right]=\mathrm{kt}
$$

where $\mathrm{X}=$ fraction of $\mathrm{ZrO}_{2}$ reacted at time $\mathrm{t}$

$$
\mathrm{k}=\text { reaction rate constant. }
$$

The relationship between $\left[1-(1-X)^{1 / 3-2}\right]$ and $t$ is shown in Fig. 8. Because the chlorination reaction of $\mathrm{ZrO}_{2}$ by $\mathrm{MoCl}_{5}$ obeyed the Jander equation in the temperature range of 473 to $668 \mathrm{~K}$, it was considered that the reaction between $\mathrm{ZrO}_{2}$ and $\mathrm{MoCl}_{5}$ was a three-dimensional diffu- 
sion reaction. The reaction rate constant was calculated from the slope of Fig. 8. The reaction rate constant of the $\mathrm{ZrO}_{2}$ chlorinated by $\mathrm{MoCl}_{5}$ was increased with the increase of the reaction temperature. The relationship between the reaction rate constant and the reciprocal of reaction temperature is shown in Fig. 9. The activation energy of reaction (7) was $67 \mathrm{~kJ} /$ mole.

\section{4 Comparison with other chlorination reactions}

Table 3 shows the activation energies of the several chlorination reactions. The activation energy of the reaction between $\mathrm{ZrO}_{2}$ and $\mathrm{MoCl}_{5}$ was smaller than that of the chlorination of $\mathrm{ZrO}_{2}$ by using $\mathrm{CCl}_{4}$ at same reaction temperature, and then was smaller than that of the other chlorination reactions using chlorine gas and carbon. The chlorination reaction between $\mathrm{ZrO}_{2}$ and $\mathrm{MoCl}_{5}$ reacted at the lowest chlorination temperature in Table 3.

In Run 9 to 11 in Table 2, the chlorination rate of the sintered $\mathrm{ZrO}_{2}$ by using $\mathrm{MoCl}_{5}$ was compared with that by using carbon and chlorine gas which was reported by Landsberg ${ }^{2}$. The chlorination rates of $\mathrm{ZrO}_{2}$ are summarized in Fig. 10. The chlorination rate was approximate-

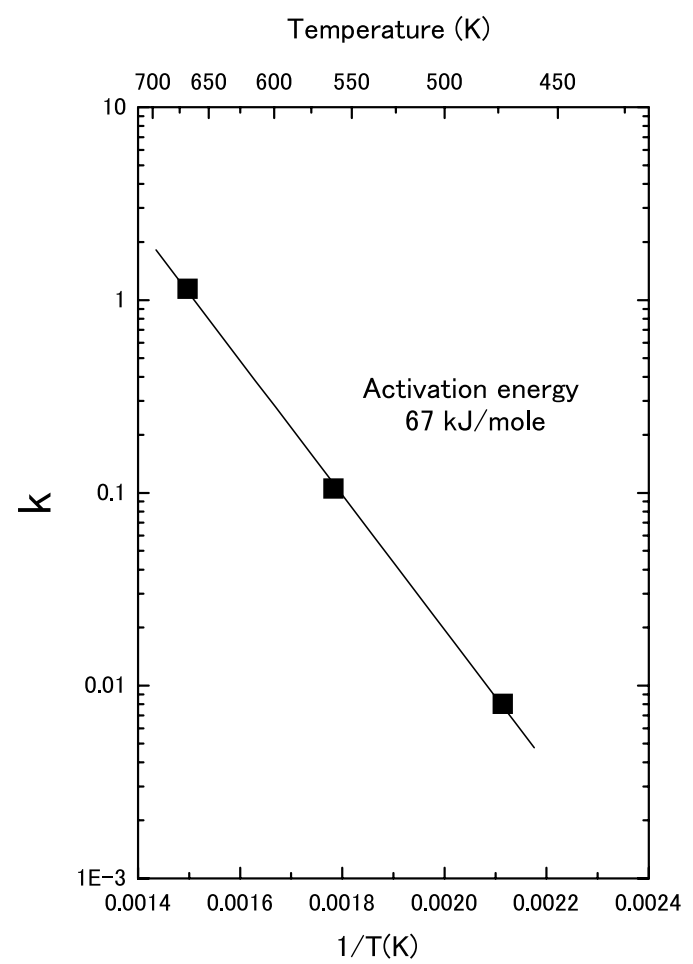

Fig. 9 Relationship between reaction rate constant and reciprocal of reaction temperature (the ratio $R_{\text {feed }}=2.6$ ). ly $10 \mathrm{mg} \cdot$ hour $^{-1} \cdot \mathrm{cm}^{-2}$ at $1300 \mathrm{~K}$ when using chlorine gas, however, for chlorination using $\mathrm{MoCl}_{5}$ the same chlorination rate was realized at only $700 \mathrm{~K}$. Consequently it is suggested that chlorination using $\mathrm{MoCl}_{5}$ has a practicable rate of reaction at lower temperature than that of chlorination using chlorine gas.

\section{Conclusion}

(1) The chlorination of $\mathrm{ZrO}_{2}$ by $\mathrm{MoCl}_{5}$ proceeded around $500 \mathrm{~K}$, and the reaction was completed in $30 \mathrm{~min}$. at 668 K.

(2) To convert all the $\mathrm{ZrO}_{2}$ to $\mathrm{ZrCl}_{4}$, the number of moles of $\mathrm{MoCl}_{5}$ must be twice that of $\mathrm{ZrO}_{2}$. The chlorination reaction between $\mathrm{ZrO}_{2}$ and $\mathrm{MoCl} 5$ is described by the equation

$\mathrm{ZrO}_{2}+2 \mathrm{MoCl}_{5}=\mathrm{ZrCl}_{4}+\mathrm{MoCl}_{4}+\mathrm{MoO}_{2} \mathrm{Cl}_{2}$

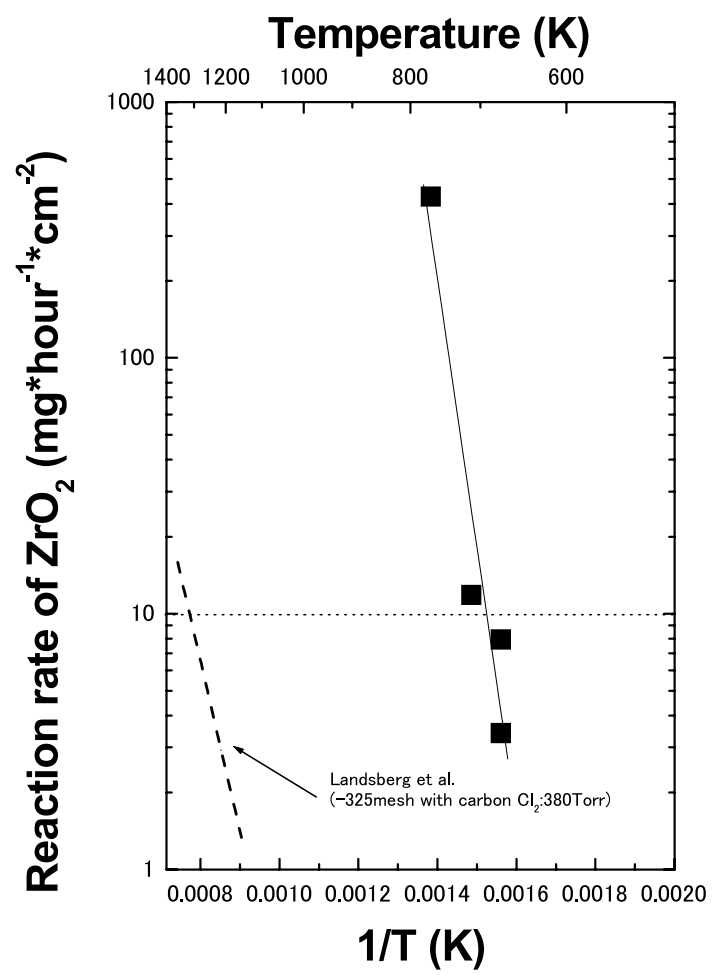

Fig. 10 The relationship between the chlorination rate of $\mathrm{ZrO}_{2}$ and chlorination temperature: The broken line presents the conversion of $\mathrm{ZrO}_{2}$ to $\mathrm{ZrCl}_{4}$ using chlorine gas and -325 mesh carbon $^{2)}$, and solid squares represent the conversion of balls of $\mathrm{ZrO}_{2}$ stabilized with $\mathrm{Y}_{2} \mathrm{O}_{3}$ to $\mathrm{ZrCl}_{4}$ using $\mathrm{MoCl}_{5}$.

Table 3 Activation energies of the several chlorination reactions.

\begin{tabular}{|c|c|c|c|c|c|c|}
\hline Chlorination reaction & $\mathrm{ZrO}_{2}$ & Reagent & $\begin{array}{l}\text { Kinetics } \\
\text { equation }\end{array}$ & $\begin{array}{l}\text { Temperature } \\
(\mathrm{K})\end{array}$ & $\begin{array}{c}\text { Activation } \\
\text { Energy } \\
(\mathrm{kJ} / \text { mole) }\end{array}$ & Reference \\
\hline \multirow[b]{2}{*}{$\mathrm{ZrO}_{2}+\mathrm{C}+\mathrm{Cl}_{2}=\mathrm{ZrCl}_{4}+\mathrm{CO}_{2}$} & Powder & $\mathrm{C}+\mathrm{Cl}_{2}$ & $\mathrm{kt}=1-(1-\mathrm{X})^{1 / 3}$ & $943-1103$ & 231 & 4 \\
\hline & Powder & $\mathrm{C}+\mathrm{Cl}_{2}$ & $\mathrm{kt}=\ln (1-\mathrm{X})$ & $1400-1700$ & 93 & 3 \\
\hline \multirow{3}{*}{$\mathrm{ZrO}_{2}+\mathrm{CCl}_{4}=\mathrm{ZrCl}_{4}+\mathrm{CO}_{2}$} & \multirow{3}{*}{ Powder } & \multirow{3}{*}{$\mathrm{CCl}_{4}$} & $\mathrm{kt}=\left(1-(1-\mathrm{X})^{1 / 3}\right)^{2}$ & $650-675$ & 278 & 1 \\
\hline & & & $\mathrm{kt}=1-(1-\mathrm{X})^{1 / 3}$ & $700-750$ & 154 & 1 \\
\hline & & & $\mathrm{Kt}=\mathrm{X}$ & $775-825$ & 54 & 1 \\
\hline $\mathrm{ZrO}_{2}+2 \mathrm{MoCl}_{5}=\mathrm{ZrCl}_{4}+\mathrm{MoCl}_{4}+\mathrm{MoO}_{2} \mathrm{Cl}_{5}$ & Powder & $\mathrm{MoCl}_{5}$ & $\mathrm{kt}=\left(1-(1-\mathrm{X})^{1 / 3}\right)^{2}$ & $473-683$ & 67 & This work \\
\hline
\end{tabular}


(3) The chlorination reaction between $\mathrm{ZrO}_{2}$ and $\mathrm{MoCl}_{5}$ is a three-dimensional diffusion reaction satisfying the Jander equation, and the activation energy is $67 \mathrm{~kJ} / \mathrm{mole}$. Chlorination of $\mathrm{ZrO}_{2}$ at a practical reaction rate using $\mathrm{MoCl}_{5}$ was realized at much lower reaction temperature than that using chlorine gas and carbon.

\section{Acknowledgements}

The authors wish to thank to Dr.T.Inoue, Dr. T. Koyama, and Dr. H.Miyashiro of CRIEPI for the useful suggestion. The authors also express his many thank to Mr. K.Ohhata for the analysis support.

\section{References}

1) P. K. Jena, E. A. Brochhi, and T. F. Villela, Met. Mat. Trans. B, 26, 235 (1995).

2) A. Landsberg, C. L. Hoatson, and F. E. Block, Met. Trans., 3, 517 (1972).

3) O. Bicerolu and W. H. Gauvin, Can. J. Chem. Eng., 58, 357 (1980).

4) A. J. Oreilly, I. D. Doig, and J. S. Ratcliffe, J. Inorg. Nucl. Chem., 34, 2487 (1972).

5) A. A. Manieh, D. S. Scott, and D. R. Spink, Can. J.
Chem. Eng, 52, 507 (1974).

6) A. A. Manieh and D. R. Spink, Can. Met. Qua., 12, 331 (1973).

7) B. D. Craig, Handbook of Corrosion Data, ASM International Metals Park, OH 44073233 (1989).

8) MALT-2: Materials-Oriented Little Thermodynamic Database for Personal Computers Ver.2, KagakuGijutsusha (1990).

9) S. A. Shchukarev, V. Vasilkovali, and B. N. Shararupin, Fiz. Khim, 22, 130 (1961).

10) O. K. Kubachewski and C. B. Alock, Metallurgical Thermochemistry, Pergamon Press Fifth Edition (1979).

11) L. Brewer, L. A. Bromley, P. W. Dilles, and N. L. Lofgren, Natl. Nucl. Energy Ser. Div. IV, B 19 (1950).

12) R. P. Burns, G. Demaria, J. Drowart, and R. T. Grimely, J. Chem. Phys., 32, 1363 (1960).

13) Powder Diffraction File PDF-2 Data Base Set 1-47, ICDD (1997).

14) R. Matsuzaki and Y. Saeki, J. Less-Common Metals 29, 427 (1972).

15) Y. Saeki and R. Matsuzaki, Denki Kagaku, 33, 155 (1965) [in Japanese].

16) A. Khawam and D. R. Flanagan, J. Phys. Chem. B, 110, 17315 (2006). 